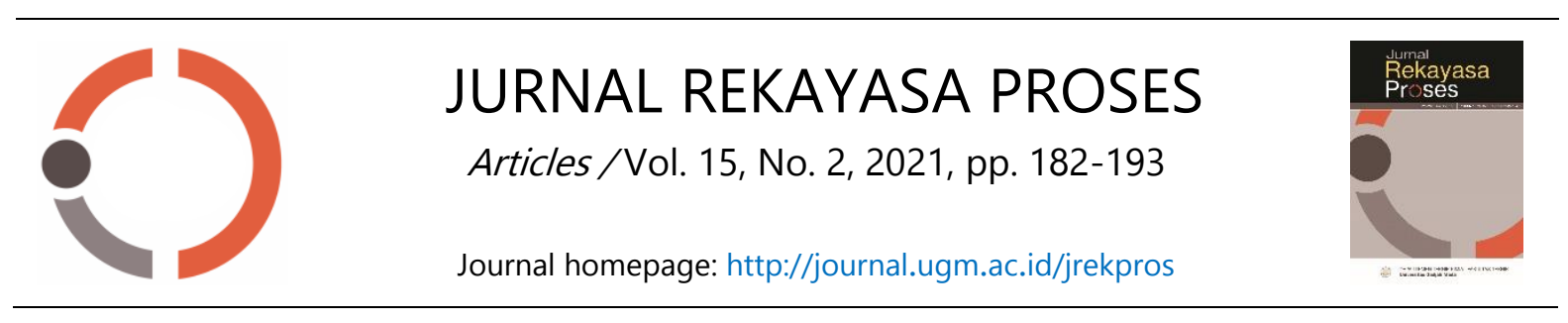

\title{
The Effect of Nutrients Mixture on The Biomass and Lipid Production from Microalgae Botryococcus braunii Mutated by UV-C Rays
}

Thea Prastiwi Soedarmodjo A, Hakun Wirawasista Aparamarta B, and Arief Widjaja C

Department of Chemical Engineering, Institut Teknologi Sepuluh Nopember, 60111 Surabaya, Indonesia

*Corresponding author: arief_w@chem-eng.its.ac.id

(Submission: 18-09-2021; Revision: 10-11-2021; Acceptance: 10-11-2021)

\section{A B S T R A C T}

Nutrient is one of the most important factors in the growth of microalgae. This research was conducted to study the effect of nutrient mixture on the biomass and lipid production of Botryococcus braunii. Microalgae $B$. braunii was cultivated in the commercial nutrient medium of agricultural fertilizer combinations of ammonium sulphate (ZA), urea, and triple superphosphate (TSP). Before the cultivation process, B. braunii was exposed to UV-C rays (254 $\mathrm{nm}$ ) for 3 minutes. The concentration and type of fertilizer as a nitrogen source divided into four types of mixtures, namely FM-1, FM-2, FM-3, and FM-4 were compared with Walne nutrients to study their effects on microalgae growth and lipids. FM-1 consisting of $150 \mathrm{mg} / \mathrm{L}$ of ZA, $7.5 \mathrm{mg} / \mathrm{L}$ of urea, and $25 \mathrm{mg} / \mathrm{L}$ of TSP led to the best growth for native and mutated microalgae strains compared to Walne nutrients and other nutrient mixtures. The mutated microalgae showed less growth than the native microalgae strains. However, the mutation process significantly increased the lipid content in the microalgae. In native microalgae strains, FM-4 consisting of $136.3 \mathrm{mg} / \mathrm{L}$ of urea and $50 \mathrm{mg} / \mathrm{L}$ of TSP produced the lowest lipid at $8.96 \%$. After being exposed to UV-C rays, the lipids in FM-4 medium increased to $55.11 \%$. The results show that the use of commercial fertilizers and exposure to UV-C rays on microalgae have high potential in preparing lipids as raw material for biodiesel which can be effectively applied in large-scale microalgae cultivation.

Keywords: Botryococcus braunii, fertilizer; microalgae; mutation; nutrient; UV-C

\section{ABSTRAK}

Nutrisi merupakan salah satu faktor terpenting dalam pertumbuhan mikroalga. Penelitian ini dilakukan untuk mempelajari pengaruh campuran nutrien terhadap biomassa dan produksi lipid Botryococcus braunii. Mikroalga B. braunii dibudidayakan pada media nutrien komersial berupa kombinasi pupuk pertanian ammonium sulfat $(Z A)$, urea, dan triple super phosphate (TSP). Sebelum proses kultivasi, B. braunii diberi paparan sinar UV-C (254 nm) selama 3 menit. 
Konsentrasi dan jenis pupuk sebagai sumber nitrogen yang dibagi menjadi empat jenis campuran, yaitu FM-1, FM-2, FM-3, dan FM-4 dibandingkan dengan nutrisi Walne untuk mempelajari pengaruhnya terhadap pertumbuhan dan lipid mikroalga. FM-1 yang terdiri dari $150 \mathrm{mg} / \mathrm{L} Z \mathrm{ZA}, 7,5 \mathrm{mg} / \mathrm{L}$ urea, dan $25 \mathrm{mg} / \mathrm{L}$ TSP menunjukkan pertumbuhan terbaik pada mikroalga alami dan termutasi dibandingkan dengan nutrisi Walne dan campuran nutrisi lainnya. Mikroalga yang termutasi menunjukkan pertumbuhan yang lebih rendah daripada mikroalga alami. Namun, proses mutasi secara signifikan meningkatkan lipid yang dikandung oleh mikroalga. Pada mikroalga alami, FM-4 yang terdiri dari 136,3 mg/L Urea dan $50 \mathrm{mg} / \mathrm{L}$ TSP menghasilkan lipid terendah sebesar 8,96\%. Setelah terpapar sinar UV-C, lipid mikrolaga dalam media FM-4 meningkat menjadi 55,11\%. Hasil penelitian menunjukkan bahwa penggunaan pupuk komersial dan paparan sinar UV-C pada mikroalga berpotensi tinggi dalam penyiapan lipid sebagai bahan baku biodiesel yang dapat diterapkan secara efektif dalam budidaya mikroalga skala besar.

\section{Kata kunci: Botryococcus braunii; mikroalga; mutasi; nutrien; pupuk;UV-C}

\section{Introduction}

Microalgae is a source of biomass that can be used as raw material in the process of making methyl esters or commonly called biodiesel. Microalgae belong to the group of eukaryotic and prokaryotic photosynthetic microorganisms, with a simple structure that allows them to grow rapidly. Microalgae have a lipid content of $20-50 \%$ and even up to $80 \%$ so that microalgae have the potential as a source of biodiesel. B. braunii is one type of microalgae that belongs to the green algae species with a fairly high lipid content, around 25-75\% (Chisti, 2007).

Under normal growth conditions, microalgae produce large amounts of biomass, but the resulting lipid content is relatively small. Genetic manipulation through mutagenesis is the most effective method to increase the productivity of various microorganisms. The use of ultraviolet light with a wavelength of $254 \mathrm{~nm}$ (UV-C) can cause more damage to deoxyribonucleic acid (DNA) because the absorption of UV radiation by DNA is at its peak. Microalgae are conditioned under stress through exposure to
UV-C rays so that their lipid content can increase (Sharma et al., 2012; Thurakit et al., 2018). The lipid content of Scenedemus sp. exposed to UV-C rays increased from $40 \%$ to $55 \%$ of dry cell weight (Sivaramakrishnan and Incharoensakdi, 2017). Sarayloo et al. (2017), also reported an increase in the content of hexadecadienoic acid (C16:2) and linolenic acid (C18:3) produced by Chlorella vulgaris after exposure to UV-C light.

Microalgae breeding methods using seawater media and the addition of nutrients are also things that need to be considered. The studies that have been carried out on a laboratory scale using analytical grade chemicals as ingredients for making highquality nutrients are not applicable in largescale microalgae cultivation. The use of agricultural fertilizers as nutrients can be easily prepared and save costs in large-scale microalgae cultivation (El Nabris, 2012).

Nitrogen and phosphorus are macro elements of the nutrients needed in microalgae cultivation. Lam and Lee (2012), examined the use of organic fertilizers in the cultivation of Chlorella vulgaris as a raw 
material for biodiesel production with a total extracted lipid of $18.1 \%$. In the research of $\mathrm{EI}$ Nabris (2012), the combination of agricultural fertilizers such as Ammonium sulphate, urea, and Calcium superphosphate resulted in the maximum average cell density of Nannochloropsis sp. of $69 \times 106 \mathrm{ml}-1$, where this combination of agricultural fertilizers is three times cheaper than the quality nutrient medium of F/2. In another study, ammoniumbased culture media was reported to produce Scenedesmus obliquus lipids of $25 \%$ dry weight (Covell et al., 2020).

This study aims to increase the lipid productivity of seawater microalgae $B$. braunii by optimizing the operating conditions for both native and mutated strains. Exposure to UV-C light and the use of commercial nutrients in $B$. braunii microalgae culture was expected to improve the quality and quantity of microalgal lipids themselves as an effective biodiesel production material applied to large-scale microalgae cultivation. Comparison between native microalgae and UV-C mutated microalgae was carried out to see the lipid yield. The effect of using commercial nutrients mixture in the form of organic fertilizers as a source of macronutrients on the resulting lipids was also compared with $B$. braunii microalgae cultured in Walne nutrient media as analytical grade chemicals nutrients.

\section{Research Methodology}

\subsection{Microalgae Culture}

Microalgae $B$. braunii strains dissolved in seawater with a ratio of 1:1 were cultured in Walne nutrient medium containing $100 \mathrm{mg} / \mathrm{L}$ NaNO3; 45 mg/L Na 2 EDTA; 33.6 mg/L H $\mathrm{BO}_{3}$; $20 \mathrm{mg} / \mathrm{L} \mathrm{NaH}_{2} \mathrm{PO}_{4} .2 \mathrm{H}_{2} \mathrm{O} ; 1.3 \mathrm{mg} / \mathrm{L} \mathrm{FeCl}_{3} .6 \mathrm{H}_{2} \mathrm{O}$;
$0.36 \mathrm{mg} / \mathrm{L} \mathrm{MnCl}_{2} .4 \mathrm{H}_{2} \mathrm{O} ; 0.1 \mathrm{mg} / \mathrm{L}$ Vitamin $\mathrm{B} 1$; $0.005 \mathrm{mg} / \mathrm{L}$ Vitamin B12 (Isnansetyo and Kurniastuty, 1995). B braunii strains were obtained from the Balai Besar Perikanan Budidaya Air Payau (BBPBAP) Jepara, Indonesia. Seawater media was obtained from the Balai Perikanan Budidaya Air Payau (BPAP) Situbondo, Indonesia with a salinity of $21 \mathrm{ppt}$. Microalgae were cultured for 7 days with a light cycle of 24 hours light and 0 hours dark. Lighting on microalgae culture was provided by 21-watt fluorescent lamps installed in two each on the top, right and left sides from the microalgae culture medium within $3 \mathrm{~cm}$, to provide light with an intensity of 6000 lux (77.08 E/m $\left.\mathrm{m}^{2} \mathrm{~s}\right)$. In microalgae culture, an aerator is installed with a flow rate of 2.5 liters/minute as an air supply. During the culture period, the number of microalgae $B$. braunii were counted every 24 hours using the counting chamber method.

\subsection{UV-C Mutation on Microalgae}

The mutagenesis process in microalgae $B$. braunii was carried out using a UV-C lamp at $254 \mathrm{~nm}$ for 3 minutes. Petri dish containing microalgae $B$. braunii was placed $3 \mathrm{~cm}$ under the UV-C lamp. The mutation process was carried out in a dark and tightly closed chamber to maximize the absorption of UV-C radiation by microalgae. Microalgae $B$. braunii which had been mutated by UV-C light were analyzed by Polymerase Chain Reaction (PCR) and compared with native microalgae.

Gene mutations that occur in B. braunii microalgae were identified by PCR analysis. The DNA extraction process of microalgae samples using the DNeasy Blood and Tissues Mini Kit (QIAGEN, Valencia, CA, USA) referred to the manufacturer's protocol. This procedure is usually used to extract tissue and 
blood, but in this study, B. braunii DNA was extracted using this procedure.

DNA was amplified by two-step PCR. The first-stage $P C R$ used a pair of universal primers, ITS1 (5-TCCGTAGGTGAACCTGCGG3) and ITS4 (5-TCCTCCGCTTATTGATATGC-3), while the second-stage PCR used a primer set targeting B. braunii, namely BITS1 (5AAGGATCATTGAACAYGTCWG-3) and BITS4 (5-TTAAGTTCAGCGGGTGCTC-3). The results of the second stage of the PCR product were analyzed by electrophoresis using $2 \%$ agarose gel.

\subsection{Effect of Nutrient Mixture}

To determine the growth of mutated and native $B$. braunii with various media conditions, it was necessary to culture $B$. braunii with a fertilizer mixture media of $Z A$, urea, and TSP. The fertilizer mixture was modified from Coutteau (1996) and divided into four types, FM-1, FM-2, FM-3, and FM-4, shown in Table 1. Microalgae were cultured for 7 days and counted every 24 hours using the counting chamber method.

Table 1. Fertilizer mixture composition for B.braunii culture medium

\begin{tabular}{ccccc}
\hline \multirow{2}{*}{ Fertilizer } & \multicolumn{5}{c}{ Concentration (mg/L) } \\
\cline { 2 - 5 } & FM-1 & FM-2 & FM-3 & FM-4 \\
\hline ZA & 150 & 100 & 300 & - \\
Urea & 7.5 & 5 & - & 136.3 \\
TSP & 25 & 15 & 50 & 50 \\
\hline
\end{tabular}

\subsection{Lipid Extraction and Analysis}

The lipid extraction process refers to a modified study by Widjaja et al. (2009). The first step for lipid extraction was the separation of microalgae from the culture medium. The separation process was started by centrifugation of microalgae and culture medium at $8500 \mathrm{rpm}$ for ten minutes. The centrifugation was kept at a temperature of $20{ }^{\circ} \mathrm{C}$. The supernatant from the centrifuge was discarded and the wet microalgae were dried at $60{ }^{\circ} \mathrm{C}$ for two hours. Microalgal lipid was extracted using n-hexane Soxhlet extraction for six hours and distilled at $70{ }^{\circ} \mathrm{C}$ for separating the solvent.

Microalgae lipids were analyzed using Shimadzu GC-2010 gas chromatography (Kyoto, Japan) to determine the quantity of glycerides and free fatty acids. The gas chromatography was equipped with a flame ionization detector (FID) and DB-5HT (5\%phenyl)-methylpolysiloxane non-polar column (15 m x $0.32 \mathrm{~mm}$ i.d., with a film thickness of $0.1 \mathrm{~m}$ ).

\subsection{Analytical Calculation}

Specific growth rate, $\mu\left(\mathrm{d}^{-1}\right)$ was defined as the change of the natural log of the cell number with time. The specific growth rate was calculated using Equation (1).

$$
\mu=\frac{1}{C_{N}} \frac{d C_{N}}{d t}=\frac{d \ln C_{N}}{d t}
$$

$C_{N}$ was the number of cells of microalgae $B$. braunii and $t$ referred to culture time.

Biomass productivity was the rate of biomass reproduction in microalgae, usually expressed in units of mass per volume per unit time. Biomass productivity was calculated using Equation (2).

$$
\begin{gathered}
\text { Biomass productivity }=\frac{C_{N t}-C_{N t O}}{t} \times \text { cell mass } \\
\text { Cell mass }=\frac{\text { biomass concentration }}{C_{N}} \\
\text { Biomass concentration }=\frac{\text { dry algae mass }}{\text { culture volume }}
\end{gathered}
$$


Lipid content expressed the percentage of lipid accumulation in microalgae based on dry weight. The calculation of lipid content could be solved using Equation (5).

$$
\text { Lipid content }=\frac{\text { crude lipid mass }}{\text { dry algae mass }} \times 100 \%
$$

Lipid productivity expressed the rate of lipid formation in microalgae in units of mass per volume per unit time. Biomass productivity was calculated by Equation (6).

Lipid productivity $=$ biomass productivity $x$ lipid content

\section{Results and Discussion}

\subsection{Microalgae Mutation}

Mutations in microorganisms aimed to improve productivity by induction of mutagens that have been used for a long time (Liu et al., 2015). In this study, UV-C light was used as a mutating agent. The number of initial B.braunii cells with the number of viable cells after exposure to UV-C light and the percentage of death are presented in Table 2. The results showed that there was a decrease in the number of viable cells after UV-C exposure for 3 minutes. Cells that were still alive after exposure to UV-C light were called mutated cells.

Table 2. Viable cells of $B$. braunii after exposure to UV$C$ light

\begin{tabular}{|c|c|c|c|}
\hline & \multicolumn{2}{|c|}{ Number of B.braunii cells } & \multirow{2}{*}{$\begin{array}{l}\text { Average } \\
\text { death cells }\end{array}$} \\
\hline & Initial cells & Mutated cells & \\
\hline Run 1 & $114,000,000.00$ & $81,666,666.67$ & \\
\hline Run 2 & $143,000,000.00$ & $104,333,333.33$ & $27.53 \%$ \\
\hline Run 3 & $148,333,333.33$ & $108,000,000.00$ & \\
\hline
\end{tabular}

There were two responses of algae to UV irradiation. First, when the algae were exposed to UV light for a short period, the
DNA structure changed, causing the algae to die. Second, long exposure time to UV light forced algae to develop methods to adapt to the side effects of UV light, which causes inhibition of algae growth (Xue et al., 2005). However, exposure to UV-C light for a longer period generated less biomass, and this will affect the lipids produced. Mutations were carried out with an exposure time of 3 minutes with an average cell death percentage of $27.53 \%$ from 3 repetitions. This study has been carried out mutations in microalgae that caused three types of death, $30 \%$, 50\%, and $70 \%$. The most optimum treatment was mutation with $30 \%$ mortality of microalgae because it showed the highest cell growth, lipid content, and lipid productivity compared to mutations with $50 \%$ and $70 \%$ mortality.

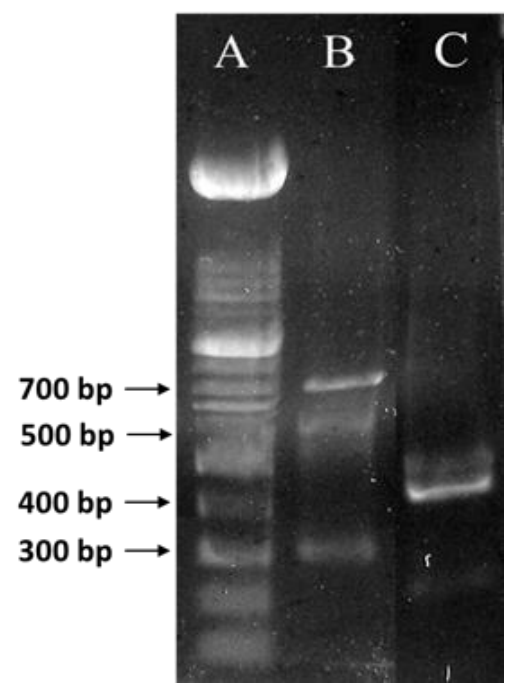

Figure 1. Electrophoresis of PCR products (A) DNA marker band (B) DNA band of UV-C mutated B.braunii (C) DNA band of native B.braunii

Gene mutations that occur in $B$. braunii microalgae were identified by PCR analysis as shown in Figure 1. Native B. braunii DNA revealed a band at $450 \mathrm{bp}$ and followed the BITS1 and BITS4 primers which specifically target the $B$. braunii species. The DNA of $B$. braunii that received mutation treatment 
using UV-C showed bands at three points, 300 bp, $500 \mathrm{bp}$, and $700 \mathrm{bp}$. These results indicated that the UV-C mutated $B$. braunii DNA has bands at different base pairs from native $B$. braunii DNA. The mutation changed the length of the base pair due to the ability of UV-C radiation to damage the cell walls, thus affecting the genetics of $B$. braunii. UV light could affect thymine bases which were capable to undergo energy changes to become active thymine bases. Two adjacent thymine bases consequent thymine dimers to coexist in DNA regions that play a role in the initiation of gene expression. UV radiation could eliminate gene expression controllers, such as cancer cells or stop gene expression altogether (Cooper, 2019).

\subsection{Effect of Nutrient Mixture on Growth of Native and UV-C Mutated B. braunii}

Figure 2 shows the growth of microalgae B. braunii for 7 days of culture in different nutrient media. Native $B$. braunii in FM-1 nutrient media produced the highest final cells when compared to Walne nutrient and other commercial nutrient mixtures. In native B. braunii, the next growth ability was shown by nutrient $\mathrm{FM}-2, \mathrm{FM}-3, \mathrm{FM}-4$, and nutrient Walne. UV-C mutated B.braunii also had a growth trend similar to native $B$. braunii, FM1 nutrient media produced the highest final number of B.braunii cells. The next growth ability was shown by nutrient FM-2, FM-3, FM-4, and nutrient Walne.

During the photosynthesis process, microalgae utilized solar energy and several important nutrients to synthesize biomass compounds and multiply cells (Markou et al., 2014). The weight ratio of fertilizers in FM-1 nutrient is the same as that in FM-2, but FM1 had higher concentrations. The macro- nutrient content in FM-1 was more available than FM-2, shown in Table 3. With these differences, native and mutated $B$. braunii in FM-1 showed better growth than FM-2. The availability of more nutrients in FM-1, especially nitrogen and phosphorus, made microalgae could multiply cells better than in FM-2. Nitrogen ( $N$ ) and phosphorus $(P)$ were major nutrients in microalgae growth (Zullaikah et al., 2019).
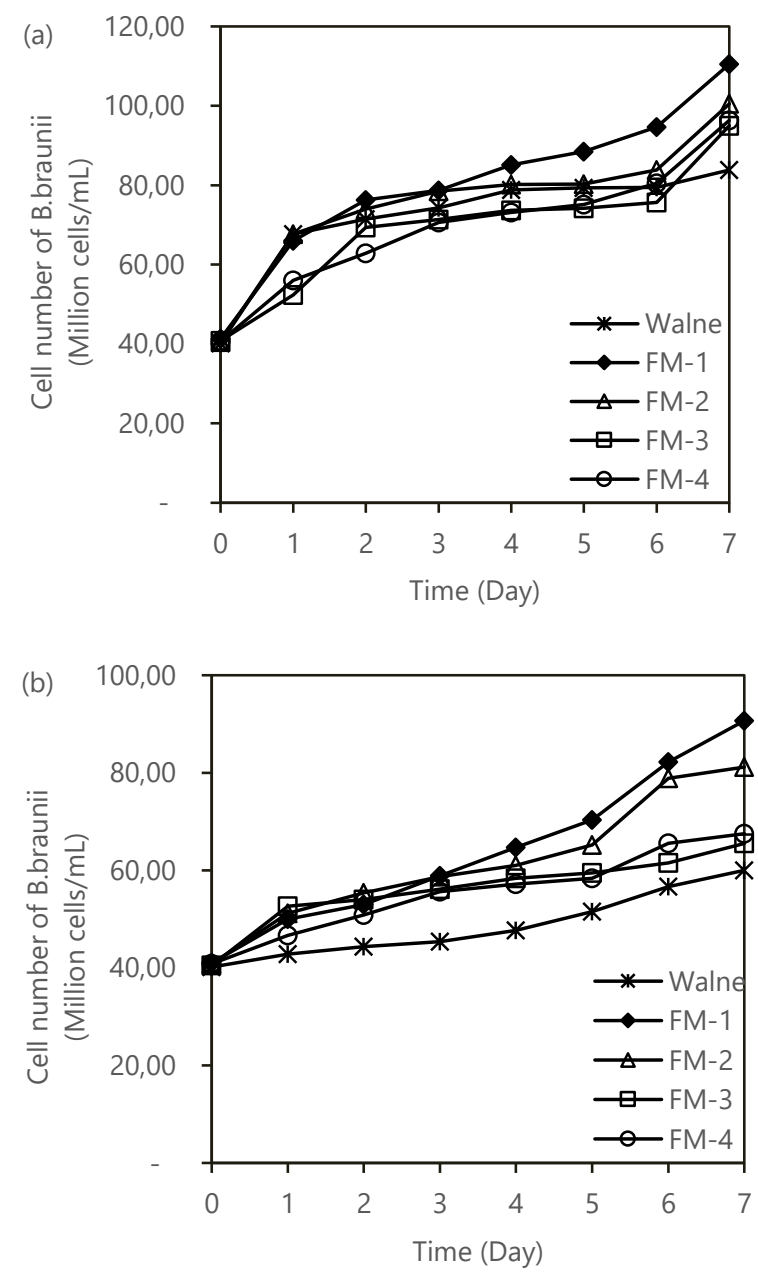

Figure 2. Cell growth curves of (a) native and (b) UV-C mutated B.braunii in different nutrient media. The composition of nutrients was as given in Table 1 in the Materials and Methods

Table 3 also shows that the nitrogen content in FM-3 and FM-4 nutrients are much higher than the nitrogen content in FM-1 and FM-2 nutrients, but the final number of cells 
in FM-3 and FM-4 nutrients are lower when compared to FM-1 and FM-2 nutrients. Nitrogen as the main nutrient could be a substance that limited the growth of microalgae. Deactivation in the generation of pigments required for photosynthesis occurred in microalgae growth media with too high a nitrogen concentration. Therefore, high nutrient concentrations take a longer period to reach the growth stability phase (Ammar, 2016).

Table 3. Comparison of nutrient content in different nutrient media

\begin{tabular}{lccc}
\hline Nutrient & \multicolumn{3}{c}{ Nutrient contents (mg/L) } \\
\cline { 2 - 4 } media & Nitrogen & Carbon & Phosphor \\
\hline Walne & 20.2307 & 16.0330 & 3.9720 \\
FM-1 & 35.3179 & 1.4996 & 6.6178 \\
FM-2 & 23.5453 & 0.9997 & 3.9707 \\
FM-3 & 63.6337 & 0 & 13.2356 \\
FM-4 & 63.6335 & 27.2559 & 13.2356 \\
\hline
\end{tabular}

Table 4 shows the comparison of the specific growth rate between Walne nutrient and commercial nutrients in native and UV-C mutated $B$. braunii. The specific growth rate of $B$. braunii in commercial nutrients was higher than Walne nutrient. In addition to nitrogen concentration, the type of nitrogen sources can also affect the growth of microalgae cells. Microalgae can utilize nitrate, ammonia, and urea as nitrogen sources (Xu et al., 2001). The nitrogen source of Walne nutrient was nitrate, while the FM-1, FM-2, and FM-3 nutrients used ammonium and FM-4 used urea as the main nitrogen source. The difference in nitrogen source affected the production of chlorophyll in microalgae. Lourenço et al. (2002) bred several seawater microalgae in a medium with three types of nitrogen sources, $\mathrm{N}$-nitrate, $\mathrm{N}$-urea, and $\mathrm{N}$-ammonium. Each type of microalgae showed a different response to the type of nitrogen source.

Table 4. Effect of nutrient media mixture on the specific growth rate of microalgae $B$. braunii

\begin{tabular}{lccccc}
\hline & \multicolumn{5}{c}{ Specific growth rate, $\boldsymbol{\mu}\left(\mathbf{d}^{-1} \mathbf{)}\right.$} \\
\cline { 2 - 6 } & Walne & FM-1 & FM-2 & FM-3 & FM-4 \\
\hline Native B.braunii & 0.105 & 0.140 & 0.130 & 0.121 & 0.123 \\
Mutated B.braunii & 0.057 & 0.113 & 0.098 & 0.069 & 0.072 \\
\hline
\end{tabular}

Although the concentration of ZA fertilizer in nutrient FM-3 was twice that in nutrient FM-1, the results showed higher cell concentrations in FM-1 nutrient than in $\mathrm{FM}-3$ nutrient. This could be attributed to the presence of urea as an additional nitrogen source in FM-1 nutrient but not in FM-3 nutrient. Apart from being a nitrogen source, urea could also be a source of organic carbon in the FM-1 nutrient. Gao et al. (2019), conducted a study on the effect of the ratio of organic carbon to nitrogen amount in microalgae Chlorella sp. At a high ratio where the amount of organic carbon was high, the specific growth rate of microalgae Chlorella $s p$. also got higher.

In addition, the high presence of ammonium ions $\left(\mathrm{NH}_{4}{ }^{+}\right)$in $\mathrm{FM}-3$ nutrient could turn into ammonia $\left(\mathrm{NH}_{3}\right)$ which is toxic. The ammonium ion was in equilibrium with ammonia in an aqueous solution. An increase in the number of ammonium ions could cause the equilibrium to shift towards ammonia. The formation of this ammonia resulted in the inhibition of the growth of microalgae cells (EI Nabris, 2012). This was also related to the growth of microalgae in FM-4 nutrient which was similar to the growth of microalgae in FM-3 nutrient. Urea as a nitrogen source in FM-4 nutrient can be decomposed into cyanate $\left(\mathrm{CNO}^{-}\right)$and ammonium ions in an aqueous solution through an elimination 
mechanism, then the cyanate ion can be converted to $\mathrm{CO}_{2}$ and ammonia (Alexandrova and Jorgensen, 2010).

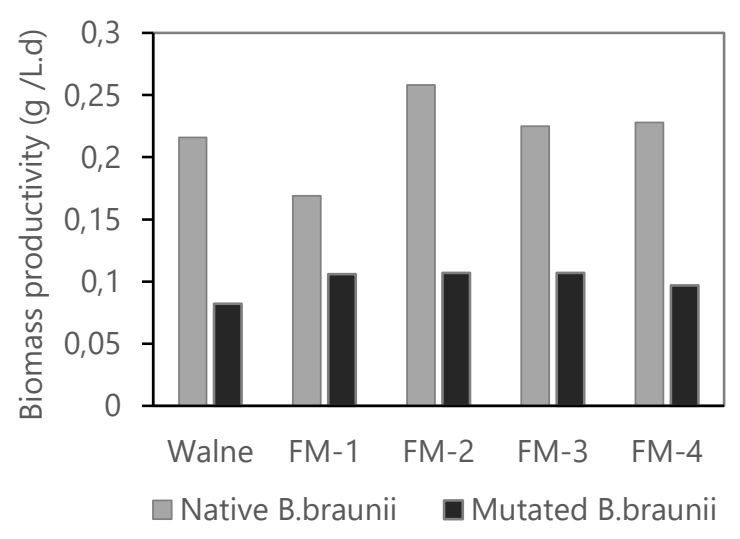

Figure 3. Comparison of biomass productivity of microalgae $B$. braunii cultured in different nutrient media

Figure 3 shows a comparison of the biomass productivity of native and mutated $B$. braunii under UV-C rays on different nutrient media. In native $B$. braunii, the highest biomass productivity was produced from microalgae cultured in FM-2 nutrient at 0.258 g/L.d. FM-1 nutrient showed the lowest biomass productivity at $0.169 \mathrm{~g} / \mathrm{L} . \mathrm{d}$. Other nutrient media did not show a significant difference. Biomass productivity of microalgae in Walne, FM-3, and FM-4 nutrients was $0.216 \mathrm{~g} / \mathrm{L} . \mathrm{d}, 0.225 \mathrm{~g} / \mathrm{L} . \mathrm{d}$, and $0.228 \mathrm{~g} / \mathrm{L}$.d. Even though microalgae in FM-1 nutrient had the highest specific growth rate, the biomass produced was not comparable to the high growth of microalgae. This could be due to the absorption of nutrients in microalgae FM-1 focused on the production of new biomass. Microalgae utilized photosynthesis to convert water and carbon dioxide into sugar through light energy. Sugars produced by photosynthesis in microalgae chloroplasts were used to support biomass growth. In the metabolic growth process, anabolism played a role in the formation of new biomass and cellular maintenance (Blanken et al., 2016).

In UV-C mutated $B$. braunii, the resulting biomass productivity did not have a significant difference in various nutrient media. The smallest biomass production was produced by mutated $B$. braunii cultured in Walne media, at $0.082 \mathrm{~g} / \mathrm{L} . \mathrm{d}$. The biomass productivity of mutated $B$. braunii cultured in commercial nutrients FM-1, FM-2, FM-3, and FM-4 was 0.106 g/L.d, 0.107 g/L.d, 0.107 g/L.d, and $0.097 \mathrm{~g} / \mathrm{L} . \mathrm{d}$. UV-C mutated $B$. braunii showed lower growth compared to native $B$. braunii. Mutation of UV-C rays caused inhibition of metabolic activity in microalgae. Exposure to UV-C light led microalgae Chlorella minutissima under stress conditions and caused a decrease in chlorophyll concentration (Borderie et al., 2014). The reduction of chlorophyll content brought a decrease in photosynthetic activity and produced lower biomass.

\subsection{Effect of Nutrient Mixture on Lipid Production of Native and UV-C Mutated B. braunii}

Figure 4 shows a comparison of the lipid content of native and UV-C mutated $B$. braunii in different nutrient media. In native $B$. braunii, the highest lipid concentration was produced by FM-1 nutrient at $21.53 \%$. When compared to the nitrogen concentration with the lipids produced by native $B$. braunii, the higher nitrogen concentration produced the lower lipid content. Nitrogen concentration affected the formation of lipids in microalgae cells. Nitrogen deficiency caused a decrease in photosynthesis and protein synthesis, but an increase in lipid and carbohydrate synthesis (Agirman and Cetin, 2017). The decrease of nitrogen levels in the substrate of 
microalgae Chlorella vulgaris increased the productivity of microalgal lipids (Widjaja et al., 2009).

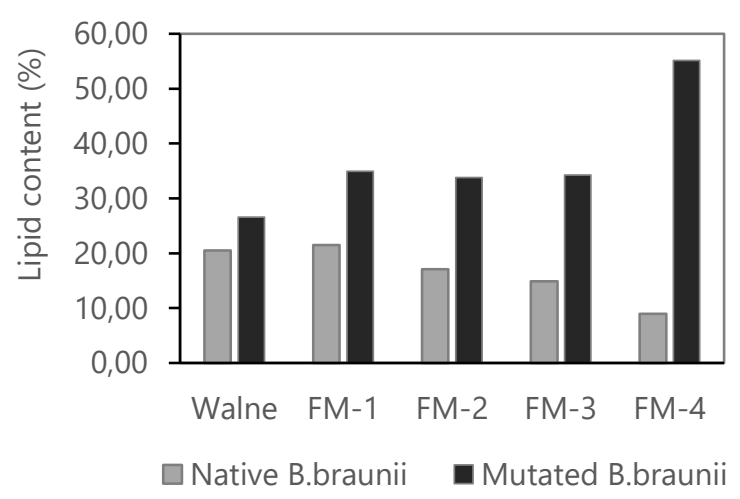

Figure 4. Comparison of the lipid content of microalgae $B$. braunii cultured in different nutrient media

An increase in lipid content of microalgae after UV-C mutation occurred in all types of culture media. This was caused by complex lipid degradation during the high-level UV irradiation process and an increase in the concentration of free fatty acids (Skerratt et al., 1998). The highest lipid concentration in UV-C mutated $B$. braunii produced by $\mathrm{FM}-4$ nutrient at $55.11 \%$, with native $B$. braunii lipid content at $8.96 \%$. It could be indicated that the microalgae $B$. braunii which had been mutated by UV-C could assimilate with urea as a nitrogen source to produce lipid better than the native microalgae $B$. braunii.

Biomass productivity and lipid content of each $B$. braunii cultured in different nutrients affected the result of lipid productivity, shown in Figure 5. In native B. braunii, FM-2 nutrient could compete with Walne nutrient. It is possible to use commercial nutrients instead of analytical nutrients based on these results. In UV-C mutated microalgae, although it produced better lipid content, the average lipid productivity produced was slightly lower than native microalgae. This was influenced by the biomass productivity of mutated $B$. braunii under UV-C rays which was lower than native $B$. braunii. In FM-4 nutrient, mutated $B$. braunii showed a very high lipid production compared to other variables.

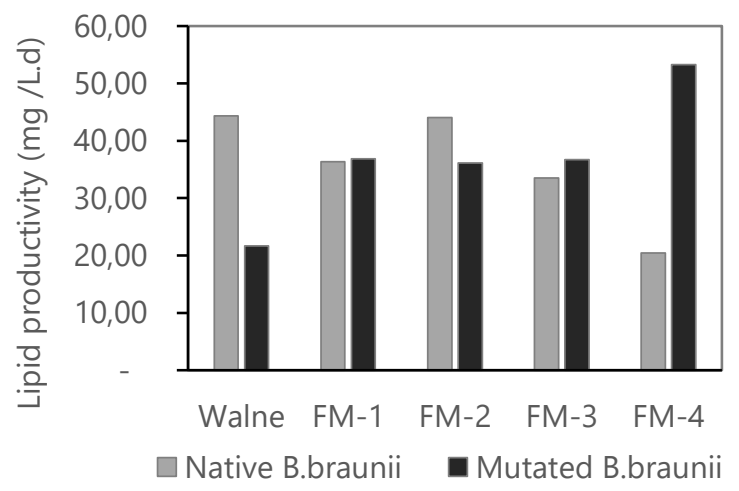

Figure 5. Comparison of lipid productivity of microalgae $B$. braunii cultured in different nutrient media

The lipid productivity of mutated $B$. braunii in Walne nutrient showed the lowest value, although the lipid productivity of native $B$. braunii in Walne nutrient was equivalent to FM-2 nutrient. In the Walne nutrient, nitrate was used as a nitrogen source, while in the commercial nutrient, ammonium was used as the main nitrogen source. The use of nitrate as the main nitrogen source was less attractive to mutated $B$. braunii resulting in the lowest productivity of biomass and lipids. The use of ammonium as a nitrogen source was reported to have better absorption than nitrate in the growth of microalgae (PerezGarcia et al., 2011).

Associated with the use of commercial nutrients, the highest lipid productivity of native $B$. braunii was produced by nutrient FM-2, while the highest lipid productivity of mutated B. braunii was produced by nutrient FM-4. The higher lipid productivity of native B. braunii in nutrient FM-2 was associated with higher biomass productivity than other 
commercial nutrients. Native $B$. braunii showed a tendency to absorb better nutrients from ammonium as the main nitrogen source compared to urea.

The highest lipid productivity of mutated B. braunii in nutrient FM-4 was related to the high level of lipid content. In addition to the mutation process that encouraged microalgae to produce more lipids, nitrogen absorption from urea also took a long time. Urea needed to be hydrolyzed to ammonia and bicarbonate before nitrogen was absorbed by microalgae cells (Perez-Garcia et al., 2011). This was equivalent to a low nitrogen state where microalgae would produce more lipids.

The lipid composition of native and UV-C mutated $B$. braunii in different nutrient media is shown in Table 5. Free fatty acid (FFA) content in all variables showed the highest results compared to other glycerides content. The distillation process in the separation of $n$ hexane solvent with microalgal lipids caused triacyl glycerides (TAG) to be hydrolyzed to FFA. This was not an issue in biodiesel manufacture. The lipid of microalgae $B$. braunii could be converted into biodiesel through transesterification and esterification processes. Ramadhani et al. (2020), carried out the conversion of biodiesel from lipid microalgae $B$. braunii by combining esterification and transesterification processes. The lipid of microalgae $B$. braunii contained $7.73 \%$ FFA and could not be converted directly through transesterification. The use of alkali catalyst in transesterification would occur a saponification reaction and prevent the formation of biodiesel. FFA in the B. braunii lipids was converted first into biodiesel through esterification with an acid catalyst and then converting TAG into biodiesel through transesterification with an alkali catalyst.

Table 5. Composition of glycerides and FFA on the lipid of microalgae B.braunii

\begin{tabular}{lcccc}
\hline \multirow{2}{*}{ Nutrient Media } & FFA & MAG & DAG & TAG \\
\cline { 2 - 5 } & \multicolumn{4}{c}{$(\%)$} \\
\hline Native B.braunii & & & \\
Walne & 56.61 & 15.35 & 0.09 & 1.58 \\
FM-1 & 61.07 & 9.16 & 0.00 & 3.53 \\
FM-2 & 41.61 & 15.11 & 3.58 & 3.00 \\
FM-3 & 30.39 & 3.32 & 0.43 & 6.62 \\
FM-4 & 60.82 & 13.20 & 0.45 & 1.70 \\
Mutated B.braunii & & & & \\
Walne & 44.22 & 16.80 & 0.76 & 1.83 \\
FM-1 & 47.63 & 19.26 & 0.12 & 2.75 \\
FM-2 & 47.55 & 18.83 & 0.05 & 1.96 \\
FM-3 & 46.65 & 21.59 & 0.14 & 1.82 \\
FM-4 & 46.23 & 22.39 & 0.72 & 1.66 \\
\hline
\end{tabular}

\section{Conclusions}

Commercial nutrients from fertilizers have the potential as a substitute for analytical nutrients. The use of ammonium sulphate and urea as nitrogen sources gave good growth results for microalgae $B$. braunii. Lipid production from microalgae cultured in commercial nutrients could also compete with Walne nutrient. UV-C mutation treatment increased the lipid content of microalgae B. braunii. Although in the ammonium sulphate-based nutrient, lipid productivity of $B$. braunii did not change significantly after mutation with UV-C rays, the use of urea as the main nutrient increased the amount of lipid content and lipid productivity of $B$. braunii.

In this study, it was observed that the difference in the main nitrogen source in the nutrient culture media was the main influence on the lipid productivity of $B$. braunii. UV-C rays mutated $B$. braunii produced higher lipid content than native $B$. braunii, but the lipid 
productivity showed a different trend with native $B$. braunii. Further research is suggested to elucidate the causes and mechanisms of this matter.

\section{Acknowledgements}

All the experimental works of this research were funded by the Directorate General of Resources for Science, Technology, and Higher Education, Ministry of Research, Technology, and Higher Education of the Republic of Indonesia. The authors expressed sincere thanks for their support.

\section{References}

Agirman, N. and Cetin, A., 2017, Effect of nitrogen limitation on growth, total lipid accumulation and protein amount in Scenedesmus acutus as biofuel reactor candidate, Nat. Sci. Discov., 3 (3), 33-33.

Alexandrova, A.N. and Jorgensen, W.L., 2010, Why Urea Eliminates Ammonia Rather Than Hydrolyzes in Aqueous Solution, J Phys Chem B., 111 (4), 720-730.

Ammar, S.H., 2016, Cultivation of Microalgae Chlorella vulgaris in airlift photobioreactor for Biomass Production using commercial NPK nutrients, Al-Khwarizmi Eng. J., 12 (1), 90-99.

Blanken, W., Postma, P.R., de Winter, L., Wijffels, R.H. and Janssen, M., 2016, Predicting microalgae growth, Algal Res., The Authors, 14, 28-38.

Borderie, F., Alaoui-sehmer, L. and Bousta, F., 2014, International Biodeterioration \& Biodegradation Cellular and molecular damage caused by high UV-C irradiation of the cave-harvested green alga Chlorella minutissima: Implications for cave management, Int. Biodeterior. Biodegradation, 93, 118-130.
Chisti, Y., 2007, Algae production comparrison, Biotechnol. Adv. 25, 25, $294-$ 306.

Cooper, G.M., 2019, The Cell: A Molecular Approach, Eighth Edition, Oxford University Press, New York.

Coutteau, P., 1996, Manual on the production and use of live food for aquaculture: Micro-algae. FAO. Belgium, FAO Fish. Tech. Pap., 7-48.

Covell, L., Machado, M., Vaz, M.G.M.V., Soares, J., Batista, A.D., Araújo, W.L., Martins, M.A., et al., 2020, Alternative fertilizer-based growth media support high lipid contents without growth impairment in Scenedesmus obliquus BR003, Bioprocess Biosyst. Eng., Springer Berlin Heidelberg, 43 (0123456789), 1123-1131.

Gao, F., Yang, H.L., Li, C., Peng, Y.Y., Lu, M.M., Jin, W.H., Bao, J.J., et al., 2019, Effect of organic carbon to nitrogen ratio in wastewater on growth, nutrient uptake and lipid accumulation of a mixotrophic microalgae Chlorella sp., Bioresour. Technol., Elsevier, 282 (March), 118-124.

Isnansetyo, A. and Kurniastuty., 1995, Teknik Kultur Phytoplankton Zooplankton, Kanisius, Yogyakarta.

Lam, M.K. and Lee, K.T., 2012, Potential of using organic fertilizer to cultivate Chlorella vulgaris for biodiesel production, Appl. Energy, Elsevier Ltd, 94, 303-308.

Liu, S., Zhao, Y., Liu, L., Ao, X., Ma, L., Wu, M. and Ma, F., 2015, Improving Cell Growth and Lipid Accumulation in Green Microalgae Chlorella sp. via UV Irradiation, Appl. Biochem. Biotechnol., 175 (7), 35073518.

Lourenço, S.O., Barbarino, E., Mancini-Filho, J., Schinke, K.P. and Aidar, E., 2002, Effects of different nitrogen sources on the growth 
and biochemical profile of 10 marine microalgae in batch culture: An evaluation for aquaculture, Phycologia, 41 (2), 158168.

Markou, G., Vandamme, D. and Muylaert, K., 2014, Microalgal and cyanobacterial cultivation: The supply of nutrients, Water Res., Elsevier Ltd, 65, 186-202.

El Nabris, K.J.-A., 2012, Development of Cheap and Simple Culture Medium for the Microalgae Nannochloropsis sp. Based on Agricultural Grade Fertilizers Available in the Local Market of Gaza Strip (Palestine), J. Al Azhar Univ. (Natural Sci., 14 (January 2012), 61-76.

Perez-Garcia, O., Escalante, F.M.E., de-Bashan, L.E. and Bashan, Y., 2011, Heterotrophic cultures of microalgae: Metabolism and potential products, Water Res., Elsevier Ltd, 45 (1), 11-36.

Ramadhani, A.P., Prashantyo, M.H., Soedarmodjo, T.P. and Widjaja, A., 2020, The effect UV-B mutation on biodiesel from microalgae Botryococcus braunii using esterification, transesterification and combination of esterificationtransesterification, AIP Conf. Proc., Vol. 2217, AIP Publishing, Indonesia : Surakarta, pp. 030021-1-030021-8.

Sarayloo, E., Tardu, M., Sabri, Y., Simsek, S., Cevahir, G. and Erkey, C., 2017, Understanding lipid metabolism in highlipid-producing Chlorella vulgaris mutants at the genome-wide level, Algal Res., Elsevier, 28 (November), 244-252.

Sharma, K.K., Schuhmann, H. and Schenk, P.M., 2012, High lipid induction in microalgae for biodiesel production, Energies, 5 (5), 1532-1553.
Sivaramakrishnan, R. and Incharoensakdi, A., 2017, Bioresource Technology Enhancement of lipid production in Scenedesmus sp ., Bioresour. Technol., Elsevier Ltd, 235, 366-370.

Skerratt, J.H., Davidson, A.D., Nichols, P.D. and McMeekin, T.A., 1998, Effect of Uv - B on Lipid Content of Three Antarctic Marine Phytoplankton, Science (80-. )., 49 (4), 9991007.

Thurakit, T., Pumas, C., Pathom-aree, W., Pekkoh, J. and Peerapornpisal, Y., 2018, Enhancement of Biomass, Lipid and Hydrocarbon Production from Green Microalga , Botryococcus braunii AARL G037, by UV-C Induction, Chiang Mai J. Sci., 45 (7), 2637-2651.

Widjaja, A., Chien, C.C. and Ju, Y.H., 2009, Study of increasing lipid production from fresh water microalgae Chlorella vulgaris, J. Taiwan Inst. Chem. Eng., 40 (1), 13-20.

Xu, N., Zhang, X., Fan, X., Han, L. and Zeng, C., 2001, Effects of nitrogen source and concentration on growth rate and fatty acid composition of Ellipsoidion sp. (Eustigmatophyta), J. OfApplied Phycol., 13, 463-469.

Xue, L., Zhang, Y., Zhang, T., An, L. and Wang, $X ., 2005$, Effects of enhanced ultraviolet-B radiation on algae and cyanobacteria, Crit. Rev. Microbiol., 31 (2), 79-89.

Zullaikah, S., Utomo, A.T., Yasmin, M., Ong, L.K. and Ju, Y.H., 2019, Ecofuel conversion technology of inedible lipid feedstocks to renewable fuel, Adv. Eco-Fuels a Sustain. Environ., Elsevier Ltd., 237-276. 